\title{
The Design and Production of Transfer Trolleys Used In Marble Industry
}

\author{
${ }^{1}$ Abdurrahman AYDIN* ${ }^{2}$ Erdem KURTMEN \\ ${ }^{1}$ Güralp Vinç ve Makina A.Ş., Research and Development Center, Izmir, Turkey \\ ${ }^{2}$ Güralp Vinç ve Makina A.Ş., Research and Development Center, Izmir, Turkey
}

\begin{abstract}
:
This study is about design and manufacturing of transfer trolleys which are used in marble cutting process in marble industry. During the cutting process, all movements are controlled by switches and control buttons. Different forces are applied on the trolley and the trolleys are exposed to an operation under water which is used for cooling the cutting tool. Since the deflection of the transfer trolley will affect the quality of cutting during the cutting process, the concrete is poured into the body of the transfer trolley to reduce the deflections during the design and to maintain a rigid body. Natural stone industry has an important place both in Turkey and world trade and it is classified as "very hazardous" for processing, modeling and finishing operations according to occupational health and safety legislations. The risks which may occur during the cutting process have been identified and taken into consideration, necessary electronic and mechanical precautions have been taken to eliminate these risks.
\end{abstract}

Key words: Marble, cutting, transfer, trolleys, transfer trolleys

\section{Introduction}

Marble is firstly used in construction business, indoor and outdoor decoration and ceramics industries $[1,2]$. There are important marble reserves in Turkey and large amount of marble is exported. Marble industry is mostly developed in Afyonkarahisar region in the west of Turkey with stone quarries and a lot of marble factories [1]. There has been an important development in this sector in Turkey after 1990 due to the customer requests for natural stones, both abroad and domestically [3]. Turkey natural stone sector is striving to become one of the world's leading natural stone producer and supplier such as China, India, Italy and Brazil with growing market day by day [3].

The production process of marble blocks is cutting or breaking of large masses from main rocks. The blocks transported to the marble processing plants are cut and sized according to their future purpose [4].

In marble industry, various machines are used to cut and size the blocks, and specially designed trolleys are used to transport the marbles [5].

*Corresponding author: Address: Güralp Vinç ve Makina Konstrüksiyon Sanayi ve Ticaret A.Ş, 35860, Torbal1, İzmir TURKEY. E-mail address: abdurrahmanaydin@guralpvinc.com.tr, Phone: +902328531866 
Transfer trolley is an important equipment used to transport marble for the cutting process in marble industry.

There are some risks such as tilting of material, drop of material, derailment, crash, during material transportation with overhead travelling crane. Since the material is not transported with the overhead travelling crane, the danger of falling over people is eliminated as a result of wire rope, lifting strap and chain breakage. Transfer trolleys are usually used to transfer loads from one hall to another or transfer to any point horizontally. Transfer trolleys have an advantage in some places where overhead travelling gantry cranes or portal cranes cannot reach. As the geometric figure of the load is cubic or prism for marble blocks, it is not necessary to connect the load with hook block as for overhead cranes. It is only placed on transfer trolley and this makes the handling process easy.

Quarrying of marbles in Turkey is mostly realized through intense man power with small scaled operations. Therefore, the preventions related to the occupational health and safety are not usually paid necessary attention and not kept under control. In order to establish more reliable working conditions in the marble quarries on account of health and safety at work, it is necessary to carry out risk analysis before the accidents occur. Risk analysis is one of the most essential constituents to be accomplished to clear away the deceases, injuries and material damages caused as results of job oriented accidents [6].

Marble quarries are investigated associated with industrial accidents using data obtained from marble quarries in Akkoyun's study. Reasons and results of accidents in quarries on industrial accidents and precautions for accidents in quarries are presented. After giving information about the machines and working parts which are at risk of accidents during the marble operation, the precautions to be taken against possible accidents are listed [7].

\section{Materials and Method}

In the choice of mechanism components and material selection, FEM and DIN standards are used. Trolleys designed with the use of group mechanism of classification in FEM and DIN standards are designed in such a way that they will not cause any problems during the service life. Directly driven wheels are preferred, because otherwise efficiency loses because of the gear, belt and pulley etc. might occur.

Each system consists of 1 sub transfer trolley (STT) and 2 top transfer trolley (TTT) as seen in the figure 1. Totally, the system consists of 12 sub transfer trolleys and 24 top transfer trolleys. The transport capacity of the top transfer trolley is 30 tons, the transport capacity of the sub transfer trolleys is $2 \times 30+2 \times 5$ tons, because top transfer trolley self weight is 5 tons.

In trolley design S275JR (St44) steel was used to produce trolley frames and C4140 (42CrMo4) was used to produce trolley wheels. Mechanical properties of S275JR and C4140 are given in Table 1 and Table 2. 
Table 1. Mechanical properties of S275JR

\begin{tabular}{ccc}
\hline & $\sigma_{Y}[\mathrm{MPa}]$ & $\sigma_{R}[\mathrm{MPa}]$ \\
\hline $\mathrm{S} 275 \mathrm{JR}$ & $275(0-16 \mathrm{~mm})$ & $410-560(3-100 \mathrm{~mm})$ \\
\hline
\end{tabular}

Table 2. Mechanical properties of C4140 (42CrMo4)

\begin{tabular}{cccc}
\hline & $\sigma_{Y}[\mathrm{MPa}]$ & $\sigma_{R}[\mathrm{MPa}]$ & HRC \\
\hline $\mathrm{C} 4140$ & $500(\varnothing 160-250 \mathrm{~mm})$ & $750-900(160-250 \mathrm{~mm})$ & $40-45$ \\
\hline
\end{tabular}

\subsection{Theory/calculation}

Trolley mechanism components are calculated and designed by making sure that they have an adequate safety factor sufficient to withstand forces causing fracture, crippling or fatigue failure.

Also, important factor is that during the lifetime of the material, forces imposed on to it do not exceed permissible limiting stress. The permissible limiting stress was to be based on the calculation of structural members of trolley. Three different loading cases are to be considered for the purpose of the calculation. Case I is the working case without wind, Case II is the working case working with wind and Case III is the working case of exceptional loadings [8].

Drive applications can be identified to three standard solutions [9]:
a. Linear movement in horizontal direction
b. Linear movement in vertical direction
c. Rotational movement

First, technical data such as masses, moments of inertia, velocities, accelerations (starting frequencies), forces, operating times, wheel diameters and shaft geometry are qualified [9].

Basic transfer trolley properties are shown in Table 3.

Table 3. Basic transfer trolley properties

\begin{tabular}{cccc}
\hline & $\begin{array}{c}\text { Load capacity } \\
\mathrm{Q}[\mathrm{kg}]\end{array}$ & $\begin{array}{c}\text { Trolley speed } \\
v[\mathrm{~m} / \mathrm{min}]\end{array}$ & $\begin{array}{c}\text { Classification of } \\
\text { mechanism }\end{array}$ \\
\hline TTT & 30000 & 7 & ISO M5 / FEM 2m \\
STT & 70000 & 7 & ISO M5 / FEM 2m \\
\hline
\end{tabular}

\subsubsection{Wheel Diameter and Rail Calculation}

In this study wheel calculations are made according to DIN15070 and FEM 1.001 standards. The wheel diameter is calculated using the following equation: 
Where:

$$
D \geq \frac{R}{p_{z u l} x c_{2} x c_{3} x\left(k-2 r_{1}\right)}
$$

D: wheel diameter $[\mathrm{mm}]$

$\mathrm{R}$ : mean wheel force $[\mathrm{N}]$

$\mathrm{k}$ : rail head width [mm]

$\mathrm{r}_{1}$ : radius of curvature of the rail head $[\mathrm{mm}]$

The values of limiting pressure (permissible pressure between wheel and rail) $\mathrm{P}_{\text {zul }}$ depend on the ultimate strength of material that the rail wheel is made are given in Table 4.

Table 4. Values of $\mathrm{P}_{\mathrm{zul}}[10]$

\begin{tabular}{cc}
\hline $\begin{array}{c}\text { Ultimate strength for } \\
\text { metal used for rail wheel }\end{array}$ & $\begin{array}{c}\mathrm{P}_{\text {zul }} \\
{\left[\mathrm{N} / \mathrm{mm}^{2}\right]}\end{array}$ \\
\hline$\sigma_{\mathrm{R}}>500 \mathrm{~N} / \mathrm{mm}^{2}$ & 5 \\
$\sigma_{\mathrm{R}}>600 \mathrm{~N} / \mathrm{mm}^{2}$ & 5,6 \\
$\sigma_{\mathrm{R}}>700 \mathrm{~N} / \mathrm{mm}^{2}$ & 6,5 \\
$\sigma_{\mathrm{R}}>800 \mathrm{~N} / \mathrm{mm}^{2}$ & 7,2 \\
\hline
\end{tabular}

The value of speed coefficient $c_{2}$ that is dependent on the speed of rotation of the wheel is given in Table 5.

Required wheel rotational speed calculated according to following equation:

$$
n[r p m]=\frac{v[\mathrm{~m} / \mathrm{min}]}{\pi \times D[\mathrm{~m}]}
$$

Table 5. Values of $c_{2}[5,9]$

\begin{tabular}{cccccccccccc}
\hline $\mathrm{n}(\mathrm{rpm})$ & 5 & 5,6 & 6,3 & 8 & 10 & 11,2 & 12,5 & 14 & 16 & 18 & 20 \\
\hline $\mathrm{c}_{2}$ & 1,17 & 1,16 & 1,15 & 1,14 & 1,13 & 1,12 & 1,11 & 1,1 & 1,09 & 1,07 & 1,06 \\
\hline
\end{tabular}

The value of coefficient $c_{3}$ that is dependent on the group classification of the mechanism is given in Table 6.

Table 6. Values of $c_{3}[10]$

\begin{tabular}{cc}
\hline Group classification of mechanism & $\mathrm{c}_{2}$ \\
\hline M1 to M4 & 1,12 \\
M5 & 1,00 \\
M6 & 0,90 \\
M7 - M8 & 0,80 \\
\hline
\end{tabular}

For cambered crane rails the ideal effective (usable) rail head width will be $\left(k-2 r_{1}\right)$. Typical cambered crane rail head according to DIN536 shown in Figure 1. 


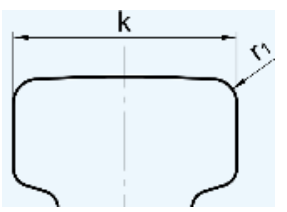

Figure 1. The cambered crane rail head dimensions

The mean wheel force is determined by the equation below for crane travelling wheels in three cases of loading I, II and III [10]:

$$
R=\frac{R_{\min }+2 R_{\max }}{3}
$$

Where:

$\mathrm{R}_{\min }$ : minimum wheel force $[\mathrm{N}]$

$\mathrm{R}_{\max }$ : maximum wheel force $[\mathrm{N}]$

The wheel force will be $R=R_{\max }$ for trolley travelling wheels. $\mathrm{R}_{\max }$ and $\mathrm{R}_{\min }$ should be determined from the most frequent operating positions of the loaded trolley.

There are several types of rail used for crane rail applications. Some are tall, some are squat and some are quite weak in some applications. The simplest calculation equation for required wheel diameter is the following equation which derived from Gantrail crane rail selection document [11]:

$$
D=\frac{1580 \times R}{k-2 r_{1}}
$$

Results of wheel diameter and rail calculation are given in Table 7.

Table 7. Results of wheel diameter and rail calculation

\begin{tabular}{cccccccccc}
\hline & $\begin{array}{c}\text { Load } \\
\mathrm{Q}[\mathrm{kg}]\end{array}$ & $\begin{array}{c}\text { Trolley } \\
\text { mass } \\
\mathrm{Q}_{\mathrm{t}}[\mathrm{kg}]\end{array}$ & $\begin{array}{c}v \\
{[\mathrm{~m} / \mathrm{min}]}\end{array}$ & $\begin{array}{c}\mathrm{D} \\
{[\mathrm{mm}]}\end{array}$ & $\begin{array}{c}\mathrm{d} \\
{[\mathrm{mm}]}\end{array}$ & $\begin{array}{c}\mathrm{a} \\
{\left[\mathrm{m} / \mathrm{s}^{2}\right]}\end{array}$ & $\begin{array}{c}\text { Rail } \\
\text { type }\end{array}$ & $\begin{array}{c}\text { Rail } \\
\text { head } \\
\text { width }\end{array}$ & $\begin{array}{c}\text { Wheel } \\
\text { quantity }\end{array}$ \\
\hline TTT & 30000 & 5000 & 7 & 315 & 80 & 0,1 & $\mathrm{~S} 49$ & 67 & 4 \\
STT & 70000 & 8000 & 7 & 400 & 90 & 0,1 & $\mathrm{~S} 49$ & 67 & 6 \\
\hline
\end{tabular}

\subsubsection{Drive Motor Power Calculation}

Ingress Protection (IP) codes are developed by the European Committee for Electro Technical Standardization (CENELEC), specifying the environmental protection the enclosure provides. IP First number is protection against solid objects, second number is protection against liquids [13, 14]. IP protection codes shown in Figure 3. According to FEM 9.683, for indoor application under normal conditions, motors must comply with IP23 (degree of protection) at least [15]. But in this application, IP56 was selected because the cutting operation is done under water. Steel protector as additional protection was made against water for motors, brakes, gearboxes and universal joint. IP protection codes are shown in Figure 2. 
Technical information is calculating the required motor power while taking the efficiencies into account.

\begin{tabular}{|c|c|c|c|}
\hline \multicolumn{2}{|r|}{ 1st number - Protection against solid objects } & \multicolumn{2}{|r|}{ 2nd number - Protection against liquids } \\
\hline $\mathbf{0}_{-}$ & No special protection & -0 & No protection \\
\hline 1 & $\begin{array}{l}\text { Protected against solid objects over } 50 \mathrm{~mm} \text {, } \\
\text { e.g. accidental touch by persons hands }\end{array}$ & -1 & $\begin{array}{l}\text { Protection against vertically falling drops of water } \\
\text { e.g. condensation }\end{array}$ \\
\hline 2 & $\begin{array}{l}\text { Protected against solid objects over } 12 \mathrm{~mm} \text {, } \\
\text { e.g. persons fingers }\end{array}$ & $-^{2}$ & $\begin{array}{l}\text { Protection against direct sprays of water up to } \\
15^{\circ} \text { from the vertical }\end{array}$ \\
\hline 3 & $\begin{array}{l}\text { Protected against solid objects over } 2.5 \mathrm{~mm} \\
\text { (tools and wires) }\end{array}$ & -3 & $\begin{array}{l}\text { Protected against direct sprays of water up to } \\
60^{\circ} \text { from the vertical }\end{array}$ \\
\hline 4 & $\begin{array}{l}\text { Protected against solid objects over } 1 \mathrm{~mm} \\
\text { (tools, wires, and small wires) }\end{array}$ & -4 & $\begin{array}{l}\text { Protection against water sprayed from all directions } \\
\text { limited ingress permitted }\end{array}$ \\
\hline 5 & $\begin{array}{l}\text { Protected against dust limited ingress (no } \\
\text { harmful deposit) }\end{array}$ & -5 & $\begin{array}{l}\text { Protected against low pressure jets of water from all } \\
\text { directions - limited ingress }\end{array}$ \\
\hline \multirow[t]{3}{*}{6} & Totally protected against dust & -6 & $\begin{array}{l}\text { Protected against temporary flooding of water, e.g. } \\
\text { for use on ship decks - limited ingress permitted }\end{array}$ \\
\hline & & -7 & $\begin{array}{l}\text { Protected against the effect of immersion between } \\
15 \mathrm{~cm} \text { and } 1 \mathrm{~m}\end{array}$ \\
\hline & & -8 & $\begin{array}{l}\text { Protects against long periods of immersion under } \\
\text { pressure }\end{array}$ \\
\hline
\end{tabular}

Figure 2. IP protection codes

$$
\begin{gathered}
F_{F}=m \times g \times\left(\frac{2}{D} \times\left(\mu_{L} x \frac{d}{2}+f\right)+c\right) \\
P_{T}=P_{D P L}+P_{S}=\frac{m \times a \times v}{\eta}+\frac{F_{F} \times v}{\eta}
\end{gathered}
$$

Where:

$\mathrm{F}_{\mathrm{F}}$ : tractive resistance force $[\mathrm{N}]$

$\mathrm{m}$ : total mass (self weight + load) $[\mathrm{N}]$

$\mu_{\mathrm{L}}$ : factor for bearing friction $(0,005$ for anti-friction bearing)

$\mathrm{d}$ : shaft diameter $[\mathrm{mm}]$

$\mathrm{f}$ : lever arm of the roller friction $[\mathrm{mm}](0,5 \mathrm{~mm})$

c: factor for rim friction and wheel flange friction ( 0,003 for anti-friction bearing)

$\mathrm{P}_{\mathrm{T}}$ : total power [W]

$\mathrm{P}_{\mathrm{DPL}}$ : dynamic power of the load [W]

$\mathrm{P}_{\mathrm{S}}$ : static power [W]

$v$ : travel speed $[\mathrm{m} / \mathrm{s}]$

$\eta$ : total efficiency $(0,85)$

a: acceleration $\left[\mathrm{m} / \mathrm{s}^{2}\right]$

Total efficiency of the drive system consisting of the gear unit efficiency and the efficiency of external transmission elements.

If the periphearal force $F_{U}$ on the driven wheel becomes greater than the friction force $F_{R}$ on the driven wheel, the wheels can start to slip.

Where:

$$
F_{U}=m \times a=F_{R}=m^{\prime} \times g \times \mu_{0}
$$

$\mathrm{m}$ ': mass lying on the driving wheels [kg] 
$\mu_{0}$ : static friction factor between steel-steel $(0.15)$

If the acceleration $a$ is smaller than the permitted acceleration $a_{p}$, the wheels cannot slip.

$$
a_{P}=\frac{1}{2} x g x \mu_{0}=0,74\left[\mathrm{~m} / \mathrm{s}^{2}\right]
$$

Results of motor power calculation are given in Table 8 .

Table 8. Results of motor power calculation

\begin{tabular}{ccccccccc}
\hline & $\begin{array}{c}\text { Load } \\
\mathrm{Q}[\mathrm{kg}]\end{array}$ & $\begin{array}{c}\text { Trolley } \\
\text { mass } \\
\mathrm{Q}_{\mathrm{t}}[\mathrm{kg}]\end{array}$ & $\begin{array}{c}v \\
{[\mathrm{~m} / \mathrm{min}]}\end{array}$ & $\begin{array}{c}\mathrm{D} \\
{[\mathrm{mm}]}\end{array}$ & $\begin{array}{c}\mathrm{d} \\
{[\mathrm{mm}]}\end{array}$ & $\begin{array}{c}\mathrm{a} \\
{\left[\mathrm{m} / \mathrm{s}^{2}\right]}\end{array}$ & $\begin{array}{c}\text { Motor } \\
\text { quantity }\end{array}$ & $\begin{array}{c}\text { Selected } \\
\text { motor power } \\
{[\mathrm{kW}]}\end{array}$ \\
\hline TTT & 30000 & 5000 & 7 & 315 & 80 & 0,1 & 1 & 1,5 \\
STT & 70000 & 8000 & 7 & 400 & 90 & 0,1 & 1 & 3 \\
\hline
\end{tabular}

\subsubsection{Trolley structure calculation}

According to FEM 1.001, the value of the permissible stress $\sigma_{a}$ is given by the following equation:

$$
\sigma_{a}=\sigma_{R} / v_{R}
$$

Where $\sigma_{R}$ is the ultimate tensile stress for the material and $v_{R}$ is a safety coefficient corresponding to each case of loading [10]. The values of $v_{R}$ are given in Table 9.

Table 9. Values of $v_{R}[10]$

\begin{tabular}{cccc}
\hline & Case I & Case II & Case III \\
\hline$v_{R}$ & 2.2 & 2.2 & 1.8 \\
\hline
\end{tabular}

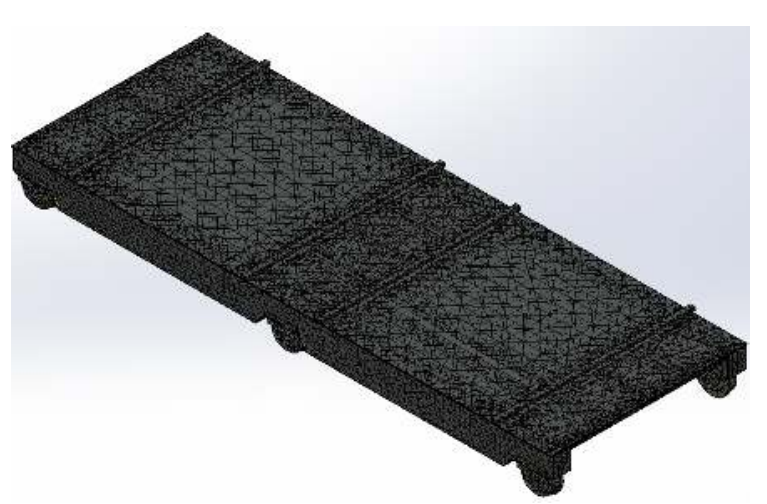

Figure 3. Mesh modeling of the transfer trolley

Mesh modeling of the trolley is shown in Figure 3. The maximum deflection is $1.128 \mathrm{~mm}$ and the stress distribution is in the range of $0-150 \mathrm{MPa}$ approximately, as seen from the stress 
distribution shown in Figure 4. It is feasible against stress, because the stress is lower than the permissible stress.

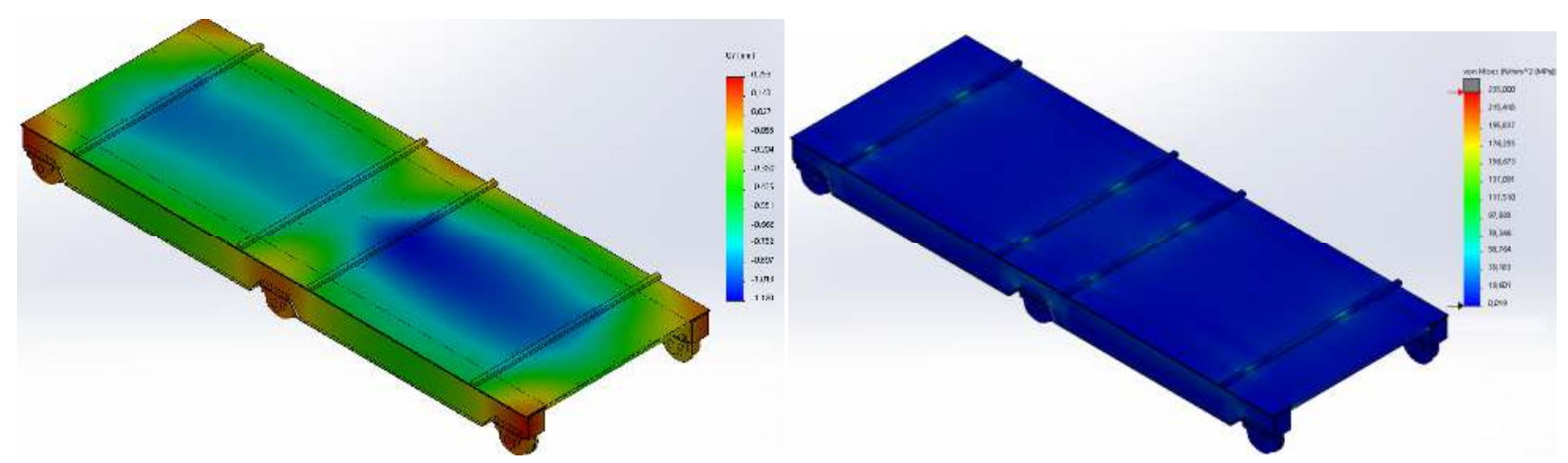

Figure 5. Results of simulation

\subsection{Trolley Design}

The assembly of the transfer trolleys can be seen in Figure 6. The railway along which each trolley moves is limited with the limit switches and mechanical bumpers. In this way, it is aimed to prevent the possibility of the accidents that may be caused by the operator. The limit switches will also perform the automatic rail alignment function of the top transfer trolleys. If the door on the railway is closed, the top transfer trolley will not move.

An emergency stop (e-stop) was placed on each of the transfer trolleys acting as a safety mechanism used to turn off machinery in a case of an emergency.

The deflection of the transfer trolley's body will affect the quality of cutting during the cutting process. The concrete is poured into the body of the transfer trolley to reduce the deflections during the design and to maintain a rigid body. The surfaces of the top transfer trolleys are covered with checkered steel plate to increase the frictional force between marble block and trolley. This way sliding of the marble blocks is prevented from happening.

Safety is the key point to be considered while electrical equipment is being included in the design. There should be no exposed areas of the cable in order to prevent electrical shock from happening. Electrical feeding systems have been selected to work under water. The top transfer trolleys will receive electricity from the spring driven cable wheel (drum) mounted on the sub transfer trolleys. The sub transfer trolley will receive electricity from the cable chain. Cable chain and spring driven cable wheel are located in the conduit against the risk of tripping over electrical cables.

The control of the triple transfer trolleys system is carried out from an electric panel. The control button is placed on the electric panel. $90 \mathrm{~dB}$ sound signal and light warning systems in all movements are placed on the electric panel. 

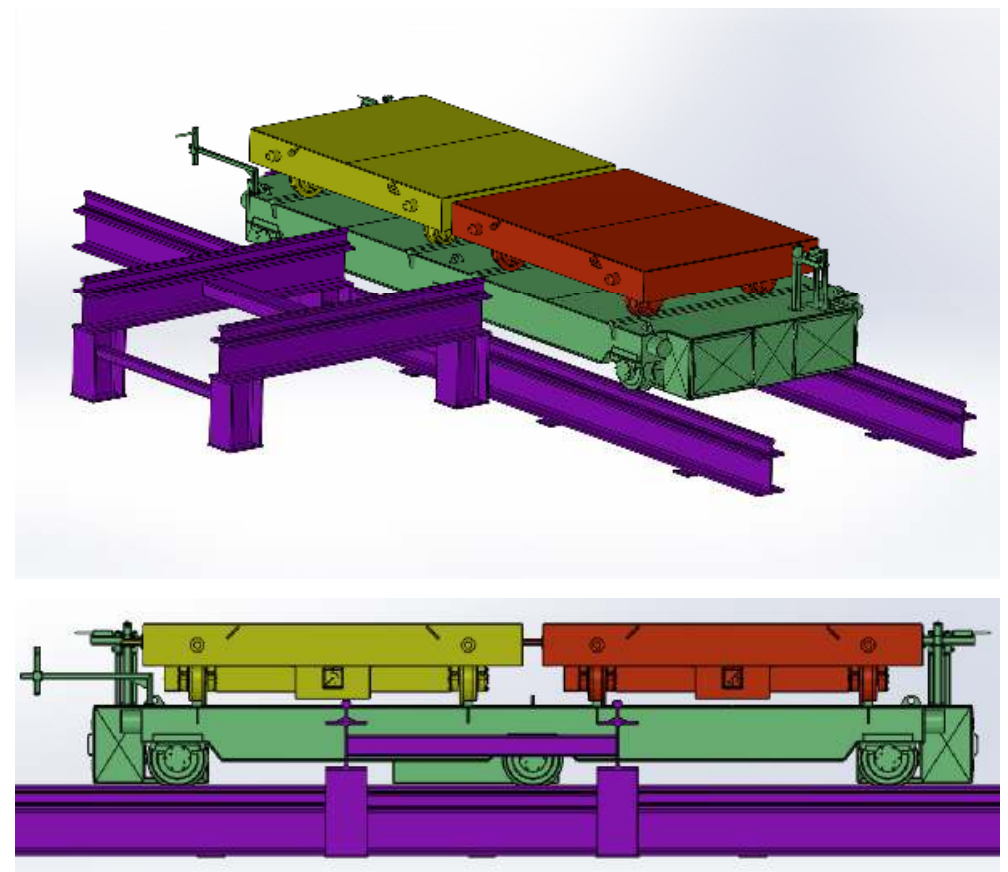

Figure 6. Transfer trolleys general drawings

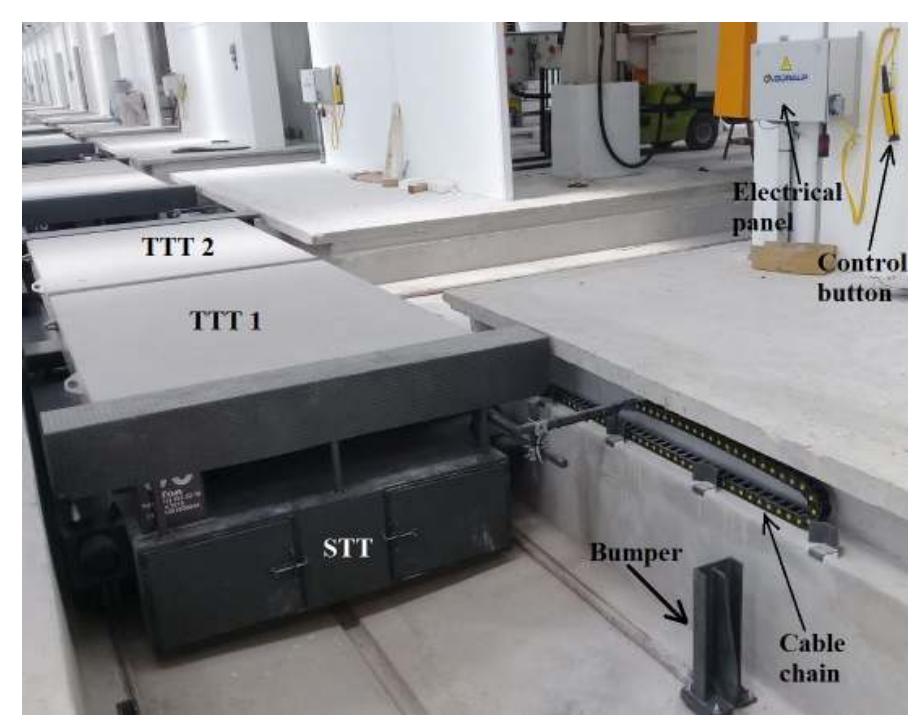

Figure 7. Transfer trolleys after installation

Transfer trolleys after installation and start-up are shown in Figure 7. Wheel groups and roller bearing housings are designed to be easily assembled and disassembled during maintenance. The trolleys have a simple lubrication system of the bearings regulated in time periods. Bearing Lubrication plays a critical role in the performance and lifetime of rolling elements. The most important role of the lubricant is to separate the moving parts relative to one another (balls or rollers and raceways) in order to decrease friction and prevent wear. 


\section{Results}

In this study, transfer trolleys are produced successfully. Before installation and start-up, a test platform was built and load tests performed with 1,25xQ static load and 1,10xQ dynamic load. The transfer trolleys successfully passed through these tests.

Mechanical equipments and facilities shall be robust, fool proofing and suitable for their intended use. The component selection and calculations should be done in accordance with the relevant international standards. The manufactured machines should be used after the tests are done. In addition, applications must be made for matters involving the most dangerous scenarios. The power and dimensions of electrical equipment must be suitable for their intended use.

\section{References}

[1] Çimen H, Çınar SM, Nartkaya M. The Investigation of Marble Cutting Parameters for Energy Consumption. International journal of mathematical models and methods in applied sciences, Issue 4, Volume 2, 2008

[2] Ersoy A, Atıcı U. Performance characteristics of circular diamond saws in cutting different types of rocks. Diamond and Related Materials, Elsevier Transactions on, Vol.13, pp 22-37, Jan. 2004.

[3] Yaman Ö. Mermer fabrikalarında ürün kalite kontrolünün görüntü analiz yöntemi ile belirlenmesi, Dokuz Eylül Üniversitesi Fen Bilimleri Enstitüsü Yüksek Lisans Tezi, 2015

[4] Ersoy M, Yeşilkaya L, Gülseven H. Mermer işleme tesislerinde moloz ve blok kesme verimlerinin karşılaştırılması. Tübav bilim dergisi, Cilt:5, Sayı:4, Sayfa:33-42, 2012

[5] Akarslan E, Çınar SM, Mermer Makineleri için Enerji Verimliği Artırıcı Kontrolör Geliştirilmesi. ELECO '2012 Elektrik - Elektronik ve Bilgisayar Mühendisliği Sempozyumu, 2012, Bursa

[6] Çınar İ, Şensögüt C. Türkiye Mermer Ocaklarında Risk Değerlendirmesi ve Uygulama Örnekleri. 8.Uluslararası Kırmataş Sempozyumu, 13-14 Ekim 2016, Kütahya-Türkiye

[7] Gümüş A, Akkoyun Ö. Mermer ocak işletmeciliğinde sık karşılaşılan iş kazaları üzerine bir inceleme, Mersem 2006, Türkiye Mermer ve Doğaltaş Sempozyumu, Afyon, 2006

[8] FEM 1.001 Booklet 2, Classification and loading on structures and mechanisms, 1998

[9] https://download.sew- eurodrive.com/download/pdf/10522913 SEW Eurodrive, Project planning of drives, date of access 26.01.2018 pdf

[10] FEM 1.001 Booklet 4, Checking for fatigue and choice of mechanism components, 1998

[11] DIN15070, Berechnungsgrundlagen für laufrader, DK 621.873-254.001.24, 197

[12] http://bexon.com.au/wp-content/uploads/2016/06/TGN_08-Crane-rail-selection-09-12.pdf

[13] https://www.engineeringtoolbox.com/ip-ingress-protection-d_452.html, date of access 26.01.2018

[14] IEC 60529. Degrees of protection provided by enclosures (IP Code). Edition 2.1 2001-02

[15] FEM 9.683. Selection of lifting and travelling motors. Federation Europeenne de la Manutention, Section IX, 1995 